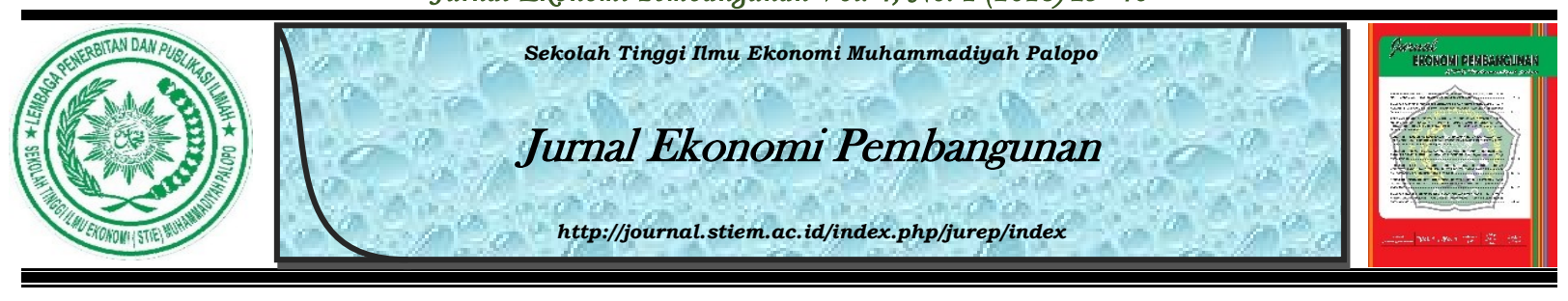

\title{
Analisis Pengelolaan Keuangan pada PT Pelabuhan Indonesia IV (Persero) Cabang Parepare
}

\author{
Nur Haerana ${ }^{1}$, Rudy Arafa ${ }^{2}$ \\ ${ }^{1,2}$ Universitas Muhammadiyah Parepare
}

\section{INFO NASKAH}

Diserahkan

23 November 2018

Diterima

23 November 2018

Diterima dan disetujui

29 Desember 2018

\section{Kata Kunci:}

Biaya operasional

Kinerja Keuangan

\begin{abstract}
ABSTRAK
Penelitian bertujuan untuk menganalisis dan mengetahui biaya operasional dan kinerja keuangan dari tahun 2011-2015 pada PT Pelabuhan Indonesia IV (Persero) Cabang Parepare. Penelitian ini menggunakan pendekatan deskriptif kuantitaif yang merupakan data angka yang dikelola dan dianalisis. Teknik pengumpulan data yang digunakan adalah observasi, wawancara, dan dokumentasi. Adapun teknik analisis data yang digunakan dalam penelitian ini untuk mengetahui biaya operasional digunakan rumus anggaran biaya operasional dan untuk mengetahui kinerja keuangan perusahaan digunakan rasio profitabilitas, rasio solvabilitas, rasio likuiditas, dan rasio aktivitas. Hasil penelitian menunjukkan bahwa tingkat anggaran biaya operasional belum efisien, karena pada tahun 2011, 2012, 2014, realisasi biaya operasional lebih besar dari anggaran yang disediakan, dan pada tahun 2013 dan 2015 anggaran biaya operasional mengalami penurunan yang disebabkan oleh rendahnya realisasi dari yang dianggarkan. Kinerja keuangan pada PT Pelabuhan Indonesia IV (Persero) Cabang Parepare dari tahun 2011-2015 dengan menggunakan analisis rasio profitabilitas, rasio solvabilitas, rasio likuiditas, dan rasio aktivitas belum efisien karena masih di bawah nilai standar rata-rata yang telah ditetapkan.
\end{abstract}

\section{Pendahuluan}

Pengelolaan perusahaan yang baik dapat meningkatkan keuntungan dan dapat mengurangi tingkat risiko kerugian perusahaan di masa yang akan datang sehingga dapat meningkatkan nilai perusahaan di masa depan. Perusahaan sebagai entitas ekonomi biasanya memiliki tujuan jangka pendek dan jangka panjang, dalam jangka pendek perusahaan bertujuan memperoleh laba secara maksimal. Sementara dalam jangka panjang tujuan utama perusahaan adalah memaksimalkan nilai perusahaan. Untuk mengetahui tingkat pencapaian tujuan perusahaan, maka secara periodik perusahaan melakukan pengukuran kinerja yang telah dicapai atau diperoleh. 
Pengelolaan keuangan dalam perusahaan merupakan kunci utama kegiatan operasional perusahaan dan tidak akan terlepas dari kegiatan yang berhubungan dengan kas. Untuk memperoleh gambaran tentang perkembangan perusahaan. Salah satunya dapat dilihat dari perkembangan keuangannya untuk menunjang keefektifan penggunaan biaya operasional perusahaan. Perusahaan memerlukan adanya analisis terhadap data keuangan dari perusahaan yang bersangkutan, yaitu analisis atau mengukur biaya-biaya umum, administrasi dan lain sebagainya.

Pernyataan Standar Akuntansi Keuangan (PSAK) Nomor 1 (2012) menetapkan dasardasar bagi penyajian laporan keuangan bertujuan umum (general purpose financial statements) yang selanjutnya disebut "laporan keuangan" agar dapat dibandingkan baik dengan laporan keuangan periode sebelumnya maupun dengan laporan keuangan entitas lain. Pernyataan ini mengatur persyaratan bagi penyajian laporan keuangan, struktur laporan keuangan, dan persyaratan minimum isi laporan keuangan.

PT Pelabuhan Indonesia IV (Persero) Cabang Parepare merupakan perusahaan milik Negara atau Badan Usaha Milik Negara (BUMN). Berdasarkan hasil pengamatan terhadap PT Pelabuhan Indonesia IV (Persero) Cabang Parepare menunjukkan bahwa lmenunjukkan bahwa selama 5 (lima) tahun terakhir efisiensi keuangan PT Pelabuhan Indonesia IV (Persero) Cabang Parepare masuk pada kategori kurang efisien. Hal itu berarti pengelolaan keuangan pada PT Pelabuhan Indonesia IV (Persero) Cabang Parepare masih perlu ditinjau kembali untuk melihat sejauh mana kinerja keuangannya. Berdasarkan hal tersebut maka peneliti ingin melakukan penelitian dengan judul penelitian "Analisis Pengelolaan Keuangan Pada PT Pelabuhan Indonesia IV (Persero) Cabang Parepare".

\section{Kajian Pustaka}

\subsection{Tinjauan Pengelolaan Keuangan}

Pengelolaan merupakan istilah yang dipakai dalam ilmu manajemen. Secara etimologi pengelolaan berasal dari kata "kelola" (to manage) dan biasanya merujuk pada proses mengurus atau menangani sesuatu untuk mencapai tujuan. Meskipun banyak ahli yang memberikan pengertian tentang pengelolaan yang berbeda-beda, namun pada prinsipnya memiliki maksud dan tujuan yang sama. Menurut Prajudidalam M. Fahri. R (2014:11), pengelolaan adalah pengendalian dan pemanfaatan semua faktor sumber daya yang menurut 
suatu perencanaan diperlukan untuk menyelesaikan suatu tujuan kerja tertentu.

\subsection{Biaya Operasional}

Menurut Mulyadi (2005:08), biaya dalam arti luas adalah pengorbanan sumber ekonomi, yang diukur dalam satuan uang, yang telah terjadi atau yang kemungkinan akan terjadi untuk tujuan tertentu. Menurut Henry Faizal Noor (2013:172) biaya (cost) adalah pengeluaran yang tidak dapat dielakkan dalam mencapai tujuan tertentu dengan kata lain, biaya adalah bagian dari pengeluaran.

\subsection{Kinerja Keuangan}

Kinerja perusahaan adalah suatu usaha formal yang dilaksanakan perusahaan untuk mengevaluasiu efisiensi dan efektivitas dari aktivitas perusahaan yang dilaksanakan pada priode waktu tertentu. Menurut Fahmi (2012:2) kinerja keuangan adalah suatu analisis untuk melihat sejauh mana suatu perusahaan telah melaksanakan dengan menggunakan aturanaturan pelaksanaan keuangan secara baik dan benar. Kinerja keuangan merupakan prestasi yang dicapai oleh perusahaan pada saat tertentu dengan menggunakan perhitungan berdasarkan tolak ukur analisis rasio yang didasarkan pada laporan keuangan. Pengukuran kinerja sangat penting untuk menilai efektivitas dan efesiensi perusahaan.

\subsection{Laporan Keuangan}

Menurut Sofyan Syafri Harahap (2013:105) laporan keuangan adalah laporan yang menggambarkan kondisi keuangan pada saat tertentu dan pada jangka waktu tertentu. Menurut PSAK (2015:1.2) tujuan laporan keuangan untuk tujuan umum adalah memberikan informasi tentang posisi keuangan, kinerja, dan arus kas perusahaan yang bermanfaat bagi sebagian besar kalangan penggunalaporan dalam rangka membuat keputusan-keputusan ekonomi serta menunjukkan pertanggung jawaban (stewardship) manajemen atas penggunaan sumbersumber daya dipercayakan kepada mereka. Dalam rangka mencapai tujuan tersebut, suatu laporan keuangan menyajikan informasi mengenai perusahaan yang meliputi:

a. Asset

b. Kewajiban 
c. Ekuitas

d. Pendapatan dan beban termasuk keuntungan dan kerugian; dan

e. Arus kas

Kasmir (2014:7) dalam pengertian sederhana laporan keuangan adalah laporan yang menunjukkan kondisi keuangan perusahaan pada saat ini atau dalam satu priode tertentu. Dalam praktiknya secara umum menurut Kasmir (2014) ada lima macam laporan keuangan yang biasadisusun, yaitu:

\section{a. Neraca}

Neraca merupakan salah satu laporan keuangan yang terpenting bagi perusahaan. Oleh karena itu, setiap perusahaan diharuskan untuk menyajikan laporan keuangan dalam bentuk neraca. Neraca biasanya disusun pada priode tertentu, misalnya satu tahun. Namun, neraca juga dapat dibuat pada saat tertentu untuk mengetahui kondisi perusahaan saat ini bila diperlukan biasanya hal ini sering dilakukan pihak manajemen pada saat tertentu. Menurut Kasmir (2014:30) neraca merupakan ringkasan laporan keuangan. Artinya, laporan keuangan disusun secara garis besarnya saja dan tidak mendetail. Kemudian, neraca juga menunjukkan posisi keuangan berupa aktiva (harta), kewajiban (utang), dan modal perusahaan (ekuitas) pada saat tertentu. Artinya neraca dapat dibuat untuk mengetahui kondisi (jumlah dan jenis) harta, utang, dan modal perusahaan. Maksud pada tanggal tertentu adalah neraca dibuat dalam waktu tertentu setiap saat dibutuhkan, namun neraca dibuat biasanya akhir tahun.

\section{b. Laporan Laba Rugi}

Menurut Kasmir (2014:29) laporan laba rugi merupakan laporan keuangan yang menggambarkan hasil usaha perusahaan dalam suatu priode tertentu. Menurut Hery (2010:25) kegunaan laporan laba rugi adalah menyajikan ukuran kebehasilan operasi perusahaan selama priode tertentu. Lewat laporan laba rugi, investor dapat mengetahui besarnya tingkat profitabilitas yang dihasilkan investe. Lewat laporan laba rugi, kreditur juga dapat mempertimbangkan kelayakan kredit debitur. 


\section{c. Laporan Perubahan Modal}

Laporan perubahan modal merupakan laporan yang berisi jumlah dan jenis modal yang dimiliki pada saat ini. Kemudian, laporan ini juga menjelaskan perubahan modal dan sebab-sebab terjadinya perubahan modal doperusahaan. Laporan perubahan modal jarang dibuat bila tidak terjadi perubahan modal. Artinya laporan ini dibuat bila memang ada perubahan modal.

\section{d. Laporan Arus Kas}

Laporan arus kas merupakan laporan yang menunjukkan semua aspek yang berkaitan dengan kegiatan perusahaan, baik yang berpengaruh langsung atau tidak langsung terhadap kas. Laporan arus kas harus disusun berdasarkan konsep kas selama priode laporan. Laporan kas terdiri arus kas masuk (cash in) dan arus kas keluar (cash out) selama priode tertentu.

\section{e. Catatan atas Laporan Keuangan}

Catatan atas laporan keuangan merupakan laporan yang memberikan informasi apabila ada laporan keuangan yang memerlukan penjelasan tertentu. Artinya terkadang ada komponen atau nilai dalam laporan keuangan yang perlu diberi penjelasan terlebi dulu sehingga jelas. Hal ini dilakukan agar pihak-pihak yang berkepentingan tidak salah menafsirkannya.

Jadi dengan memperoleh laporan keuangan suatu perusahaan, akan dapat diketahui kondisi keuangan perusahaan secara menyeluruh. Kemudian laporan keuangan tidak hanya sekedar cukup dibaca saja, tetapi juga harus dimengerti dan dipahami tentang posisi keuangan perusahaan saat ini. Caranya adalah melakukakn analisis keuangan melalui berbagai rasio keuangan yang lazim dilakukan.

\subsection{Analisis Rasio}

Menurut Kasmir (2013:104) rasio keuangan merupakan kegiatan membandingkan angkaangka yang ada dalam laporan keuangan dengan cara membagi satu angka dengan angka lainnya. Perbandingan dapat dilakukan antara satu komponen dengan komponen dalam satu laporan keuangan. Kemudian angka yang dibandingkan dapat berupa angka-angka dalam satu 
periode maupun beberapa periode.

Analisis rasio keuangan digolongkan beberapa bagian untuk menilai kinerja perusahaan.

a. Rasio Profitabilitas

Menurut Kasmir (2014:196) rasio profitabilitas merupakan rasio untuk menilai kemampuan perusahaan dalam mencari keuntungan dalam suatu priode tertentu. Rasio profibilitas ini memberikan ukuran tingkat efektivitas manajemen suatu perusahaan.

b. Rosia Solvabilitas

Rasio solvabilitas adalah rasio yang diguanakan untuk mengukur sejauh mana aktiva perusahaan dibiayai dengan utang. Artinya berapa besar beban utang yang ditanggung perusahaan dibandingkan dengan aktivanya. Dalam arti luas dikatakan bahwa rasio solvabilitas digunakan untuk mengukur kemampuan perusahaan untuk membayar seluruh kewajibannya, baik jangka pendek maupun jangka panjang, Kasmir (2014:151).

c. Rasio Likuiditas

Rasio Likuidatas bertujuan untuk mengetahui kemampuan perusahaan dalam membayar kewajiban-kewajiban jangka pendeknya (likuiditasnya). Rasio likuiditas atau sering disebut rasio modal kerja merupakan rasio yang digunakan untuk mengukur seberapa likuidnya suatu perusahaan. Caranya dengan membandingkan komponen yang ada di neraca, yaitu total aktiva lancar dengan total utang lancar (utang jangka pendek). Penilaian dapat dilakukan untuk beberapa priode sehingga terlihat perkembangan likuiditas perusahaan dari waktu ke waktu.

\section{d. Rasio Aktivitas}

Rasio Aktivitas (activity ratio) merupakan rasio yang digunakan untuk mengukur efektivitas perusahaan dalam menggunakan aktiva yang dimilikinya. Hasil pengukuran ini, dapat diketahui berbagai hal yang berkaitan dengan aktivitas perusahaan sehingga manajemen dapat mengukur kinerja mereka selama ini. 


\section{Metode Penelitian}

\subsection{Desain Penelitian}

Penelitian ini berlangsung di PT Pelabuhan Indonesia IV (Persero) Cabang Parepare. Waktu yang dibutuhkan untuk penelitian selama 3 bulan dari bulan April-Juni tahun 2016 dengan interval waktu tersebut diharapkan penelitian ini rampung secara tuntas. Pendekatan penelitian yang digunakan adalah deskriptif kuantitatif. Tujuan deskriptif kuantitatif yaitu menggambarkan bagaimana biaya operasional dan kinerja keuangan pada PT Pelabuhan Indonesia IV (Persero) Cabang Parepare.

\subsection{Jenis dan Sumber Data}

Jenis data yang digunakan dalam penelitian ini adalah data kuantitatif. Data kuantitatif yaitu data yang merupakan kumpulan informasi yang bersifat angka-angka seperti neraca dan laba rugi. Sumber data dalam penelitian ini yaitu:

a. Person, merupakan data yang diperoleh melalui personal dalam instansi itu sesuai dengan pokok pembahasan.

b. Paper, merupakan data yang diperoleh berupa laporan tertulis atau biasa disebut dengan dokumen yang signifikan terkait dengan masalah yang diteliti.

c. Place, merupakan data yang diperoleh dari suatu tempat penelitian baik secara lisan maupun tulisan.

\subsection{Teknik Pengumpulan Data}

Teknik pengumpulan data yang digunakan untuk memperoleh data dan informasi yang diperlukan dalam penelitian ini adalah:

a. Observasi

Observasi yaitu dengan melakukan pengamatan secara langsung dilapangan (lokasi penelitian)

b. Interview

Interview yaitu dengan menggunakan wawancara dengan pimpinan manajer dan beberapa responden terkait dengan penelitian. 
c. Dokumentasi

Dokumentasi yaitu mengadakan penelitian terhadap laporan kegiatan operasional perusahaan dan struktur organisasi.

\subsection{Teknik Analisis Data}

Rumus yang digunakan untuk mengetahui biaya operasional pada PT Pelabuhan Indonesia IV (Persero) Cabang Parepare, dengan menggunakan analisis anggaran biaya operasional. Menurut Trisnadi Wijaya, dkk (2012), adalah sebagai berikut:

$$
\text { anggaran BO }=\frac{\text { Realisasi Anggaran }}{\text { Yang dianggarkan }} \times 100 \%
$$

Adapun rumus yang digunakan untuk mengetahui kinerja keuangan pada PT. Pelabuhan Indonesia IV (Persero) Cabang Parepare, dengan menggunakan analisis rasio. Adapun rumus yang digunakan untuk menganalisis rasio menurut Kasmir (2014), sebagai berikut:

a. Rasio Profitabilitas

$$
R O A=\frac{\text { EBIT }(\text { Earning Befor Tax })}{\text { Total Aktiva }} \times 100 \%
$$

b. Rasio Solvabilitas

$$
\text { Debt Ratio }=\frac{\text { Total Utang }}{\text { Total Aktiva }} \times 100 \%
$$

c. Rasio likuiditas

$$
\text { currenratio }=\frac{\text { Aktiva Lancar }}{\text { Utang Lancar }} \times 100 \%
$$

d. Rasio Aktivitas

$$
T A T O=\frac{\text { Total Pendapatan }}{\text { Total Aktiva }} \mathrm{X} 100 \%
$$




\section{Hasil dan Pembahasan}

\subsection{Hasil Penelitian}

Tabel 1. Anggaran realisasi Biaya Operasional Tahun 2011-2015

\begin{tabular}{|c|c|c|c|}
\hline Tahun & Anggaran (Rp) & Realisasi (Rp) & $\%$ \\
\hline 2011 & 5.389 .567 .000 & 5.714 .786 .481 & 106 \\
\hline 2012 & 6.678 .228 .000 & 7.167 .436 .846 & 107 \\
\hline 2013 & 9.813 .702 .000 & 9.273 .435 .347 & 94 \\
\hline 2014 & 9.604 .679 .000 & 10.700 .742 .293 & 111 \\
\hline 2015 & 11.666 .969 .000 & 11.526 .142 .076 & 99 \\
\hline
\end{tabular}

Sumber: Olahan Data PT Pelabuhan Indonesia IV (Persero) Cabang Parepare

Tabel 2. Rasio Profitabilitas

\begin{tabular}{|c|c|c|c|}
\hline Tahun & EBT (Rp) & Total Aktiva (Rp) & ROA \\
\hline 2011 & 3.559 .681 .862 & 22.653 .009 .860 & 16 \\
\hline 2012 & 4.379 .317 .870 & 25.519 .909 .709 & 17 \\
\hline 2013 & 4.407 .507 .813 & 30.896 .846 .367 & 14 \\
\hline 2014 & 6.087 .063 .973 & 31.517 .206 .642 & 19 \\
\hline 2015 & 5.381 .571 .963 & 59.632 .998 .858 & 9 \\
\hline
\end{tabular}

Sumber: Olahan Data PT Pelabuhan Indonesia IV (Persero) Cabang Parepare

Tabel 3. Rasio Solvabilitas

\begin{tabular}{|c|c|c|c|}
\hline Tahun & Total Aktiva $(\mathrm{Rp})$ & Total Utang (Rp) & Debt Rasio \\
\hline 2011 & 22.653 .009 .860 & 1.195 .196 .224 & 5 \\
\hline 2012 & 25.519 .909 .709 & 704.536 .471 & 3 \\
\hline 2013 & 30.896 .846 .367 & 3.321 .319 .265 & 11 \\
\hline 2014 & 31.517 .206 .642 & 1.875 .907 .122 & 6 \\
\hline 2015 & 59.632 .998 .858 & 1.890 .241 .807 & 3 \\
\hline
\end{tabular}

Sumber: Olahan Data PT Pelabuhan Indonesia IV (Persero) Cabang Parepare 
Tabel 4. Rasio Likuiditas

\begin{tabular}{|c|c|c|c|}
\hline Tahun & Aktiva Lancar (Rp) & Utang Lancar (Rp) & Current rasio \\
\hline 2011 & 65.885 .412 & 469.732 .137 & 14 \\
\hline 2012 & 1.068 .886 .278 & 478.017 .945 & 223 \\
\hline 2013 & 1.144 .232 .226 & 3.094 .800 .739 & 37 \\
\hline 2014 & 998.173 .966 & 1.944 .854 .596 & 51 \\
\hline 2015 & 1.282 .796 .254 & 1.890 .241 .807 & 68 \\
\hline
\end{tabular}

Sumber: Olahan Data PT Pelabuhan Indonesia IV (Persero) Cabang Parepare

Tabel 5. Rasio Aktivitas

\begin{tabular}{|c|c|c|c|}
\hline Tahun & Total Pendapatan $(\mathrm{Rp})$ & Total Aktiva $(\mathrm{Rp})$ & Tato \\
\hline 2011 & 9.274 .468 .342 & 22.653 .009 .860 & 41 \\
\hline 2012 & 11.546 .754 .719 & 25.519 .909 .709 & 45 \\
\hline 2013 & 13.781 .464 .775 & 30.896 .846 .367 & 45 \\
\hline 2014 & 16.787 .806 .266 & 31.517 .206 .642 & 53 \\
\hline 2015 & 16.907 .714 .039 & 59.632 .998 .858 & 28 \\
\hline
\end{tabular}

Sumber: Olahan Data PT Pelabuhan Indonesia IV (Persero) Cabang Parepare

\subsection{Pembahasan}

\section{Biaya Operasional}

Berdasarkan hasil perhitungan, anggaran biaya operasional pada PT Pelabuhan Indonesia IV (Persero) Cabang Parepare. Diketahui bahwa anggaran biaya operasioanl dari tahun 20112015, mengalami fluktuasi setiap tahunnya, karena pada tahun 2011 biaya operasional pada PT. Pelabuhan Indonesia IV (Persero) Cabang Parepare, menunjukkan bahwaanggaran biaya operasional pada perusahaan sebesar 106\% disebabkan karena besarnya realisasi sebesar Rp5.714.786.481 dan anggaran sebesar Rp5.389.567.000, pada tahun 2012 meningkat sebesar 107\%, hal ini disebabkan besarnya realisasi sebesar Rp7.167.436.846 dibanding anggaran sebesar Rp6.678.702.000 pada tahun 2013 biaya operasional pada perusahaan turun menjadi 94\%, hal ini disebabkan karena rendahnya realisasi perusahaan sebesar Rp9.273.435.347 dibanding yang dianggarkan perusahaan sebesar Rp9.813.702.000 pada tahun 2014 meningkat 
lagi menjadi 111\% disebabkan karena meningkatnya pula realisasi perusahaan sebesar Rp10.700.742.293 dan menurunnya anggaran perusahaan sebesar Rp9.604.679.000 dan pada tahun 2015 turun menjadi 99\% karena jumlah realisasi sebesar Rp11.526.142.076 dan anggaran sebesar Rp11.666.969.000.

\section{Kinerja Keuangan}

Berdasarkan hasil perhitungan kinerja keuangan PT Pelabuhan Indonesia IV (Persero) Cabang Parepare, menunjukan bahwa hasil perhitungan dari tahun 2011-2015 mengalami fluktuasi atau masih dibawah nilai standar rata-rata yang telah ditetapkan.

Tabel 6. Kinerja Keuangan

\begin{tabular}{|l|c|c|c|c|}
\hline Tahun & Profitabilitas & Solvabilitas & Likuiditas & Aktivitas \\
\hline 2011 & $16 \%$ & $5 \%$ & $14 \%$ & $41 \%$ \\
\hline 2012 & $17 \%$ & $3 \%$ & $223 \%$ & $45 \%$ \\
\hline 2013 & $14 \%$ & $11 \%$ & $37 \%$ & $45 \%$ \\
\hline 2014 & $19 \%$ & $6 \%$ & $51 \%$ & $53 \%$ \\
\hline 2015 & $9 \%$ & $3 \%$ & $68 \%$ & $28 \%$ \\
\hline Total & $\mathbf{7 5 \% / 5}$ & $\mathbf{2 8 \% / 5}$ & $\mathbf{3 9 3} \% / \mathbf{5}$ & $\mathbf{2 1 2 \%} / \mathbf{5}$ \\
\hline Rata-rata & $\mathbf{1 5 \%}$ & $\mathbf{6 \%}$ & $\mathbf{7 9 \%}$ & $\mathbf{4 2 \%}$ \\
\hline
\end{tabular}

\section{Rasio Profitabilitas}

Rasio profitabilitas pada PT Pelabuhan Indonesia IV (Persero) Cabang Parepare dari tahun 2011-2015. Dimana pada tahun 2011 tingkat presentasinya menunjukkan sebesar 16\% dapat dikatakan baik karena berada di atas nilai rata-rata perusahaan, pada tahun 2012 rasio ini meningkat dengan persentasi sebesar $17 \%$, rasio ini berada diatas rata-rata perusahaan, pada tahun 2013 rasio ini menurun dengan tingkat persentasi 14\%, dapat dikatakan kurang baik, karena rasio ini berada di bawah nilai rata-rata perusahaan, pada tahun 2014 kembali meningkat dengan persentasi sebesar 19\% rasio ini berada di atas nilai rata-rata perusahaan, dan pada tahun 2015 kembali menurun dengan tingkat persentasi sebesar 9\%, rasio ini berada di bawah nilai rata-rata perusahaan.

Dikatakan di bawah nilai rata-rata perusahaan apabila hasil perhitungan rasio di bawah $15 \%$, dan dikatakan di atas nilai rata-rata apabila hasil perhitungan di atas $15 \%$. Penurunan 
rasio ini disebabkan karena rendahnya laba dan meningkatnya aktiva yang dimiliki, dan sebaliknya peningkatan rasio ini disebabkan karena tingginya laba dan meningkatnya pula aktiva yang dimiliki perusahaan. Semakin tinggi rasio ini maka semakin besar perusahaan dalam memperoleh keuntungan.

Jadi dapat dikatakan bahwa rasio profitabilitas pada PT Pelabuhan Indonesia IV (Persero) Cabang Parepare dari tahun 2011-2015 belum efisien, karena masih berada dibawah nilai standar rata-rata yang telah ditetapkan.

\section{Rasio Solvabilitas}

Rasio Solvabilitas pada PT Pelabuhan Indonesia IV (Persero) Cabang Parepare dari tahun 2011-2015 mengalami fluktuasi. Dimana pada tahun 2011 tingkat presentasinya sebesar 5\% dapat dikatakan baik karena berada di bawah nilai rata-rata perusahaan, pada tahun 2012 rasio ini menurun dengan persentasi sebesar 3\%, rasio ini berada di bawah rata-rata perusahaan, pada tahun 2013 rasio ini meningkat dengan tingkat persentasi 11\%, dapat dikatakan kurang baik, karena rasio ini berada di atas nilai rata-rata perusahaan, pada tahun 2014 kembali menurun dengan persentasi sebesar $6 \%$ rasio ini berada di nilai rata-rata perusahaan, dan pada tahun 2015 kembali menurun dengan tingkat persentasi sebesar 3\%, rasio ini berada di bawah nilai rata-rata perusahaan.

Dikatakan di bawah nilai rata-rata perusahaan apabila hasil perhitungan rasio di bawah $6 \%$, dan dikatakan di atas nilai rata-rata apabila hasil perhitungan diatas 6\%. Peningkatan rasio ini disebabkan total aktiva yang menurun menyebabkan rasio tinggi, begitu pula apabila total utang menurun maka total aktiva meningkat menyebabkan rasio rendah. Semakin tinggi rasio ini menunjukkan perusahaan semakin berisiko.

Jadi dapat dikatakan bahwa rasio solvabilitas pada PT Pelabuhan Indonesia IV (Persero) Cabang Parepare dari tahun 2011-2015 sudah efisien, karena berada dibawah nilai standar rata-rata yang telah ditetapkan.

\section{Rasio Likuiditas}

Rasio Likuiditas pada PT Pelabuhan Indonesia IV (Persero) Cabang Parepare dari tahun 2011-2015. Dimana pada tahun 2011 tingkat presentasinya sebesar 14\% dapat dikatakan kurang baik karena berada di bawah nilai rata-rata perusahaan, pada tahun 2012 rasio ini 
meningkat dengan persentasi sebesar 223\%, dapat dikatakan baik karena rasio ini berada di atas rata-rata perusahaan, pada tahun 2013 rasio ini kembali menurun dengan tingkat persentasi $37 \%$, dapat dikatakan kurang baik, karena rasio ini berada di atas nilai rata-rata perusahaan, pada tahun 2014 meningkat dengan persentasi sebesar 51\% rasio ini berada di atas nilai rata-rata perusahaan, dan pada tahun 2015 tingkat persentasinya sebesar $68 \%$, rasio ini berada di bawah nilai rata-rata perusahaan.

Dikatakan di bawah nilai rata-rata perusahaan apabila hasil perhitungan rasio di bawah $79 \%$, dan dikatakan di atas nilai rata-rata apabila hasil perhitungan diatas $79 \%$. Penurunan rasio ini karena besarnya utang lancar dibanding aktiva lancar, dan peningkatan rasio ini karena meningkatnya aktiva lancar yang dimiliki perusahaan. Semakin tinggi rasio ini semakin besar kemampuan perusahaan dalam memenuhi utang lancarnya.

Jadi dapat dikatakan bahwa rasio likuiditas pada PT Pelabuhan Indonesia IV (Persero) Cabang Parepare dari tahun 2011-2015 belum efisien, atau masih berada dibawah nilai standar rata-rata yang telah ditetapkan.

\section{Rasio Aktivitas}

Rasio Aktivitas pada PT Pelabuhan Indonesia IV (Persero) Cabang Parepare dari tahun 2011-2015. Dimana pada tahun 2011 tingkat persentasinya sebesar 41\% dapat dikatakan kurang baik karena berada di bawah nilai rata-rata perusahaan, pada tahun 2012 dan 2013 rasio ini meningkat dengan masing-masing persentasi sebesar $45 \%$, dapat dikatakan baik karena rasio ini berada di atas rata-rata perusahaan, pada tahun 2014 kembali meningkat dengan persentasi sebesar 53\% rasio ini berada di atas nilai rata-rata perusahaan, dan pada tahun 2015 tingkat persentasinya kembali menurun sebesar 28\%, rasio ini berada di bawah nilai rata-rata perusahaan.

Dikatakan di bawah nilai rata-rata perusahaan apabila hasil perhitungan rasio di bawah $42 \%$, dan dikatakan di atas nilai rata-rata apabila hasil perhitungan diatas $42 \%$. Rendahnya rasio ini disebabkan total pendapatan rendah sedangkan total aktiva tinggi, begitupun sebaliknya peningkatan rasio ini disebabkan karena total pendapatan meningkat seiring meningkatnya total aktiva. Semakin tinggi rasio ini maka semakin baik pula aktivitas yang dilakukan perusahaan.

Jadi dapat dikatakan bahwa rasio aktivitas pada PT Pelabuhan Indonesia IV (Persero) 
Cabang Parepare dari tahun 2011-2015 belum efisien, atau masih berada dibawah nilai standar rata-rata yang telah ditetapkan.

\section{Simpulan dan Saran}

Anggaran biaya operasional pada PT Pelabuhan Indonesia IV (Persero) Cabang Parepare dari tahun 2011-2015, pada tahun 2011, 2012 dan 2014 realisasi biaya operasional pada PT. Pelabuhan Indonesia IV (Persero) Cabang Parepare lebih besar dari pada anggaran atau terjadi penyimpangan yang tidak menguntungkan. Pada tahun 2013 dan 2015 realisasi biaya operasional pada PT Pelabuhan Indonesia IV (Persero) Cabang Parepare lebih rendah dari anggaran. Kinerja keuangan pada PT Pelabuhan Indonesia IV (Persero) Cabang Parepare dari tahun 2011-2015 dengan menggunakan analisis rasio profitabilitas, rasio solvabilitas, rasio likuiditas, dan rasio aktivitas. Kinerja keuangan PT Pelabuhan Indonesia IV (Persero) Cabang Parepare, belum efisien, karena pada rasio likuiditas masih dibawah standar rata-rata yang telah ditetapkan.

Adapun saran dalam penelitian ini adalah hendaknya pihak Manajemen yang berkaitan dengan penganggaran di Perusahaan lebih teliti, akurat didalam menentukan asumsi-asumsi yang dipergunakan dalam penyusunan anggaran, agar pencapaian realisasi anggaran lebih optimal, dan mengoptimalkan pelaksanaan pengen dalian yang telah ditetapkan, agar hasil yang dicapai sesuai yang dianggarkan. Kinerja keuangan harus ditinjau secara terus menerus agar perubahan-perubahan yang terjadi pada keuangan perusahaan dapat terlihat dengan jelas dan pihak manajeman dapat berantisipasi dengan cepat mengambil keputusan untuk kemungkinan-kemungkinan yang bisa saja terjadi dimasa yang akan datang serta untuk lebih meningkatkan kinerja perusahaan sekarang dan untuk masa yang akan datang. Selain itu, untuk peneliti berikutnya, diharapkan dapat menganalisis BUMN lain, sehingga dapat digunakan sebagai dasar untuk menilai kinerja keuangan perusahaan secara umum.

\section{Daftar Pustaka}

Ali, I. 2014. Analisis Efektivitas Biaya Operasional dalam Pelaksanaan Anggaran pada PT PLN (Persro) Sektor Pembangkit Bakaru Kota Parepare. Skripsi, Fakultas Ekonomi, Universitas muhammadiyah Parepare. 
Dedy Saputra, I. 2008. Analisis Biaya Operasional pada CV Rahmat P Siantara. Skripsi, Fakultas Ekonomi, Universitas Sumatera Utara.

Fahmi. 2012. Kinerja Keuangan. http://tipsserbaserbi.blogspot.com/2015/03/pengertiankinerja-keuangan-menurut.html, di akses: 14 April 2016.

Fahri M.R. 2014. Efektivitas Pengelolaan Keuangan Daerah Di Sektor Pendidikan Kota Parepare. Skripsi, Fakutas Ekonomi, Universitas Muhammadiyah Parepare.

Harahap, S.S. 2013. Analisis Krisis Atas Laporan Keuangan. Jakarta: Rajawali Pers.

Herlina. 2013. Analisis Biaya Operasional Terhadap Realisasi Target Pendapatan Perusahaan Pada PT PLN (Persero) Area Parepare. Skripsi, Fakultas Ekonomi, Universitas Muhammadiyah Parepare.

Hery. 2010. Soal-Jawaban Akuntansi Menengah. Jakarta: Bumi Aksara.

Ikatan Akuntansi Indonesia. 2012. Standar Akuntansi Keuangan. Jakarta: Salemba Empat.

Jumingan. 2006. Analisis Laporan Keuangan. Jakarta: Bumi Aksara.

Karno, S.S.D., R. Effendi, dan T Wijaya. 2012. Analisis Anggaran Biaya Operasional dan Anggaran Pendapatan Terhadap Kinerja Keuangan Berdasarkan Rasio Return on Asset (ROA) pada PT. Graha Sarana Duta Palembang.

Kasmir. 2010. Pengantar Manajemen Keuangan. Jakarta: Kencana.

Kasmir. 2014. Analisis Laporan Keuangan. Jakarta: Rajawali.

Kuswandi. 2006. Memahami Rasio-Rasio Keuangan Bagi Orang Awam. Jakarta: PT Elex Media Kompotindo.

Muhammad, A. 2013. Analisis Kinerja Keuangan Perusahaan Daerah Air Minum Parepare. Skripsi, Fakultas Ekonomi, Universitas Muhammadiyah Parepare.

Mulyadi. 2005. Akuntansi Biaya. Edisi 5. Yogyakarta: Graha Ilmu.

Murhadi, W.R. 2013. Analisis Laporan Keuangan Proyeksi dan Valuasi Saham. Jakarta: Selemba Empat.

Noor, H.F. 2013. Ekonomi Manajerial. Edisi Revisi. Jakarta: Rajawali Pers.

Raiborn, C.A. dan M.A. Kinney. 2011. Akuntansi Biaya. Edisi 7. Jakarta: Selemba Empat.

Rezky, K.A. 2011. Analisis Kinerja Keuangan pada PT Mega Indah Sari Makassar. Skripsi, Fakultas Ekonomi, Universitas Hasanuddin Makassar. 
Sadeli, L.M. 2010. Dasar-Dasar Akuntansi. Jakarta: Bumi Aksara.

Saraswati, D., 2013. Analisis Laporan Keuangan Sebagai Alat Penilaian Kinerja Keuangan pada Koperasi Universitas Brawijaya Malang Priode 2009-2012. Jurnal Administrasi Bisnis, 6 (2): 1-10.

Siregar, B., B. Suripto, D. Hapsoro, E. Widodo, dan F. Biyanto. 2013. Akuntansi Manajemen. Jakarta: Selemba Empat.

Soekanto. 2011. Pengertian Pengelolaan, Pengertian Perencanaan dan Pengertian Pelaksanaan.

http://www.pengertianpakar.com/2014/12/pengertian-pengelolaanperencanaan-dan.html

Syarifuddin. 2005. Pengelolaan Keuangan. http://elib.unikom.ac.id/download.php?id=42362

Yuli, A. 2009. Analisis Pengendalian Biaya Operasional pada PT Pelabuhan Indonesia 1 (Persero) Medan. Skripsi, Fakultas Ekonomi, Universitas Sumatera Utara. 